\title{
More Benefits of Automation
}

\author{
Malcolm Getz
}

More benefits of an automated library system are described, measured, and valued in dollar terms. The benefits include the automated circulation system as well as an automated catalog and are measured from the library user's point of view. The dollar value of the annual benefit of the automated circulation system is substantial. Additional benefits of the automated catalog are found over those described in May 1987.

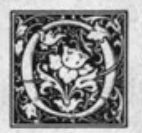

n May, 1987, this journal reported the author's effort to chronicle "Some Benefits of the Online Catalog. ${ }^{1}$ In this essay, a measure of the benefit of the online circulation system is added and the first assessment is reviewed. As before, the goal is to develop and test methods for measuring how users benefit from changes in library services. If the method proves persuasive, then the benefits can be repeatedly measured in a number of libraries and increase our understanding of these particular actions.

In 1984, the Heard Library at Vanderbilt University used a card catalog and a keysort card circulation system. In 1985, they introduced the online catalog called Acorn using NOTIS software, and in 1986, they introduced the online circulation system component of the integrated system. To measure the effect of these developments, the time required to find and charge a known item was observed before and after the change, as well as the success of library users in finding specific items. The improvements are valued in dollar terms.

\section{LIBRARY USE}

Library users were asked to complete forms indicating how they used the library. The survey form was revised from the previous years to allow users to record the nature of their use of the electronic tools now in the library. Surveys were conducted during randomly chosen twohour time blocks of the 1987 Spring semester, during day, evening, and weekend hours. In all, 1,125 responses were usable as shown in table 1.

Table 1 indicates the proportion of respondents who engaged in finding and reading tasks. The proportion who engaged in finding tasks is higher in 1987 (51.6 percent) than in 1986 (41.9 percent) and the increase might be attributed to the growing popularity of the electronic system. The proportion of respondents who engage in reading tasks is also higher, but there is no ready explanation for this change.

Table 2 compares the pattern of finding activities in 1986 with those observed in 1987. Catalog use increased sharply in the second full year of Acorn operation, as the system grew and users gained confidence in it. Tables 3 and 4 report changes in patterns of reading and other tasks. Table 5 reports the low card catalog use in 1987.

The extent of catalog searching in 1986,

Malcolm Getz is Associate Provost for Information Services and Technology at Vanderbilt University, Nashville, Tennessee 37203. Angela Maddux led the survey and statistical work underlaying this study, and her efforts are much appreciated. 
early in the life of Acorn, is compared with its second year, 1987. In 1986, 17.6 percent of the respondents engaged in author-title searches of the catalog, while in 1987, 31.6 percent used Acorn for author-title catalog searching. The increase in known-item searching suggests that the electronic catalog has had a significant effect on how users, especially students, use the library. A value is assigned to this increase below.

Similarly, the subject searching has increased from 12.5 percent of visits to 23.1 percent of visits.

\section{ACCESS TIME}

Paul Kantor's "Measure of Access Time by Simulation"'2 method is again used to record the average time to locate a known item and charge it, given the citation, and a group of relatively inexperienced student users is again compared with a group of experienced student library employees. Table 6 compares the simulation times for 1986 with those for 1987.

According to the results for inexperienced users on lines $A$ and $B$ of table 6 , the catalog time looks lower in 1987 than in 1986. However, the 1986 observations had very high variances, so the test for the difference in means is not valid. Perhaps in the second year of the electronic catalog even inexperienced users have somewhat more experience. Time to find the item in the stacks remains unchanged and nothing has changed to affect stack time. ${ }^{3}$

The time to return from the stacks with the item and present it for charge falls by one minute, fourteen seconds from 1986 to 1987 . This decrease is statistically significant and reflects the introduction of the bar code-based automated circulation component of Acorn (i.e., readers need not fill out cards). Time to check out the book, once it is presented to the library staff person, is unchanged by the automated circulation system.

The times for the experienced users, lines $C$ and $D$ of table 6 , show no significant change except for the "return from stacks." Here experienced users save one minute, twenty-three seconds, on average from not having to complete a card to charge a book. This is 78.5 seconds on average for experienced and inexperienced users.
The times of the experienced with the inexperienced users can be compared. In 1987 , with an integrated online catalog and circulation system, the time difference at the catalog for a known-item search no longer differs between experienced and inexperienced users. The fortyeight-second average for the experienced users is not a statistically significant difference from the fifty-four-second average for the inexperienced users. The convergence of search times for inexperienced and experienced users reflects the power of a well-designed electronic search tool. It allows inexperienced users to search with the speed of experienced users.

Experienced users do record a thirteensecond shorter average time to return from the stacks than the inexperienced users (one minute, thirteen seconds versus one minute, twenty-six seconds). Perhaps experienced users know their way around the library better.

\section{THE VALUE OF TIME SAVED}

Assuming that, on average, library users save 78.5 seconds for each book charged from the library because of the automated circulation system (the mean between experienced and inexperienced users), multiplying this number by the number of items charged and converting to hours gives the number of hours saved per year by not completing cards. By valuing the time at appropriate hourly rates as discussed in the 1987 essay, an annual dollar benefit of the automated circulation component of the integrated system can be computed. ${ }^{4}$ Figure 1 shows the calculation.

Column $A$ reports the number of persons entering the library per year, figures from the most recent year for which the entrance turnstiles give complete data. Column $B$ repeats from table 4 the proportion of respondents who say they checked out a book during their visit. Column $C$ multiplies column $A$ by column $B$ times 2.45 on the assumption that each user who charges out books averages 2.45 books per visit. Our estimate of the number of visits is divided by the books charged into the annual circulation figure to arrive at the 2.45 books charged per transaction. Column $C$, then, indicates the number of 
TABLE 1

LIBRARY USE COUNT OF RESPONDENTS

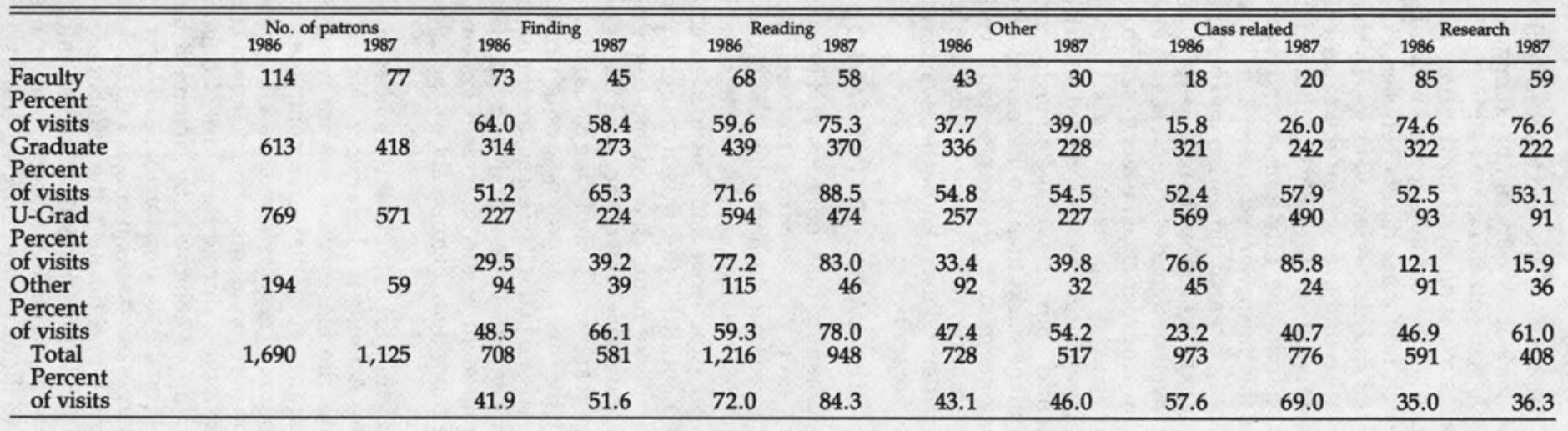

TABLE 2

FINDING TASKS

\begin{tabular}{|c|c|c|c|c|c|c|c|c|c|c|c|c|c|c|c|c|c|c|}
\hline \multirow{3}{*}{$\begin{array}{l}\text { Faculty } \\
\text { Percent of visits } \\
\text { Percent of finding tasks }\end{array}$} & \multirow{2}{*}{\multicolumn{2}{|c|}{$\begin{array}{c}\text { No. of } \\
\text { Patrons } \\
1986 \quad 1987 \\
\end{array}$}} & \multirow{2}{*}{\multicolumn{2}{|c|}{$\begin{array}{c}\text { Catalog } \\
\text { Author/ } \\
\text { Title } \\
\text { Search } \\
1986 \quad 1987 \\
\end{array}$}} & \multirow{2}{*}{\multicolumn{2}{|c|}{$\begin{array}{c}\text { Catalog } \\
\text { Subject } \\
\text { Search } \\
1986 \quad 1987 \\
\end{array}$}} & \multirow[t]{2}{*}{$\begin{array}{l}\text { Acorn } \\
\text { Author/ } \\
\text { Title } \\
\text { Search } \\
1987 \\
\end{array}$} & \multirow[t]{2}{*}{$\begin{array}{l}\text { Acorn } \\
\text { Subject } \\
\text { Search } \\
1987 \\
\end{array}$} & \multicolumn{2}{|c|}{$\begin{array}{l}\text { Search } \\
\text { Periodical } \\
\text { Index }\end{array}$} & \multirow{2}{*}{\multicolumn{2}{|c|}{$\begin{array}{c}\text { Ask } \\
\text { Librarian } \\
\text { or Staff } \\
1986\end{array}$}} & \multirow{2}{*}{\multicolumn{2}{|c|}{$\begin{array}{c}\text { Browse } \\
1986 \quad 1987\end{array}$}} & \multicolumn{2}{|c|}{$\begin{array}{c}\text { Total } \\
\text { Respondents }\end{array}$} & \multirow{2}{*}{\multicolumn{2}{|c|}{$\begin{array}{c}\text { Total } \\
\text { Finding } \\
\text { Tasks } \\
198{ }^{\quad 1987} \\
\end{array}$}} \\
\hline & & & & & & & & & 1986 & 1987 & & & & & 1986 & 1987 & & \\
\hline & 114 & 77 & $\begin{array}{r}43 \\
37.7 \\
48.3\end{array}$ & $\begin{array}{r}34 \\
44.2 \\
45.9\end{array}$ & $\begin{array}{r}5 \\
4.4 \\
5.6\end{array}$ & $\begin{array}{r}12 \\
15.6 \\
16.2\end{array}$ & $\begin{array}{r}30 \\
39.0 \\
30 / 6\end{array}$ & $\begin{array}{r}11 \\
14.3 \\
11.2\end{array}$ & $\begin{array}{r}8 \\
7.0 \\
9.0\end{array}$ & $\begin{array}{r}9 \\
11.7 \\
12.2\end{array}$ & $\begin{array}{r}16 \\
14.0 \\
18.0\end{array}$ & $\begin{array}{r}9 \\
11.7 \\
12.2\end{array}$ & $\begin{array}{r}17 \\
14.9 \\
19.1\end{array}$ & $\begin{array}{r}10 \\
13.0 \\
13.5\end{array}$ & $\begin{array}{r}73 \\
64.0\end{array}$ & $\begin{array}{r}45 \\
58.4\end{array}$ & $\begin{array}{r}89 \\
78.1\end{array}$ & $\begin{array}{r}74 \\
96.1\end{array}$ \\
\hline $\begin{array}{l}\text { Grad/Professional } \\
\text { Percent of visits } \\
\text { Percent of finding tasks }\end{array}$ & 613 & 418 & $\begin{array}{r}137 \\
22.3 \\
26.5\end{array}$ & $\begin{array}{r}189 \\
45.2 \\
38.2\end{array}$ & $\begin{array}{r}98 \\
16.0 \\
19.0\end{array}$ & $\begin{array}{r}116 \\
27.8 \\
23.4\end{array}$ & $\begin{array}{r}182 \\
43.5 \\
28.6\end{array}$ & $\begin{array}{r}103 \\
24.6 \\
16.2\end{array}$ & $\begin{array}{r}118 \\
19.2 \\
22.8\end{array}$ & $\begin{array}{r}73 \\
17.5 \\
14.7\end{array}$ & $\begin{array}{r}74 \\
12.1 \\
14.3\end{array}$ & $\begin{array}{r}53 \\
12.7 \\
10.7\end{array}$ & $\begin{array}{r}90 \\
14.7 \\
17.4\end{array}$ & $\begin{array}{r}64 \\
15.3 \\
12.9\end{array}$ & $\begin{array}{r}314 \\
51.2\end{array}$ & $\begin{array}{r}273 \\
65.3\end{array}$ & $\begin{array}{r}517 \\
84.3\end{array}$ & $\begin{array}{r}495 \\
118.4\end{array}$ \\
\hline $\begin{array}{l}\text { Undergraduate } \\
\text { Percent of visits } \\
\text { Percent of finding tasks }\end{array}$ & 769 & 571 & $\begin{array}{r}80 \\
10.4 \\
20.9\end{array}$ & $\begin{array}{r}120 \\
21.0 \\
28.8\end{array}$ & $\begin{array}{r}83 \\
10.8 \\
21.7\end{array}$ & $\begin{array}{r}118 \\
20.7 \\
28.3\end{array}$ & $\begin{array}{r}114 \\
20.0 \\
22.5\end{array}$ & $\begin{array}{r}110 \\
19.3 \\
21.7\end{array}$ & $\begin{array}{r}64 \\
8.3 \\
16.7\end{array}$ & $\begin{array}{r}36 \\
6.3 \\
8.6\end{array}$ & $\begin{array}{r}91 \\
11.8 \\
23.8\end{array}$ & $\begin{array}{r}64 \\
11.2 \\
15.3\end{array}$ & $\begin{array}{r}65 \\
8.4 \\
17.0\end{array}$ & $\begin{array}{r}79 \\
13.8 \\
18.9\end{array}$ & $\begin{array}{r}227 \\
29.5\end{array}$ & $\begin{array}{r}224 \\
39.2\end{array}$ & $\begin{array}{r}383 \\
49.8\end{array}$ & $\begin{array}{r}417 \\
73.0\end{array}$ \\
\hline $\begin{array}{l}\text { Other } \\
\text { Percent of visits } \\
\text { Percent of finding tasks }\end{array}$ & 194 & 59 & $\begin{array}{r}37 \\
19.1 \\
27.6\end{array}$ & $\begin{array}{r}14 \\
23.7 \\
23.0\end{array}$ & $\begin{array}{r}26 \\
13.4 \\
19.4\end{array}$ & $\begin{array}{r}18 \\
30.5 \\
30.0\end{array}$ & $\begin{array}{r}11 \\
18.6 \\
14.3\end{array}$ & $\begin{array}{r}10 \\
17.0 \\
13.0\end{array}$ & $\begin{array}{r}18 \\
9.3 \\
13.4\end{array}$ & $\begin{array}{r}6 \\
10.2 \\
9.8\end{array}$ & $\begin{array}{r}27 \\
13.9 \\
20.1\end{array}$ & $\begin{array}{r}8 \\
13.6 \\
13.1\end{array}$ & $\begin{array}{r}26 \\
13.4 \\
19.4\end{array}$ & $\begin{array}{r}15 \\
25.4 \\
24.6\end{array}$ & $\begin{array}{r}94 \\
48.5\end{array}$ & $\begin{array}{r}39 \\
66.1\end{array}$ & $\begin{array}{r}134 \\
69.1\end{array}$ & $\begin{array}{r}61 \\
103.4\end{array}$ \\
\hline $\begin{array}{l}\text { Total } \\
\text { Percent of visits } \\
\text { Percent of finding tasks }\end{array}$ & 1,690 & 1,125 & $\begin{array}{r}297 \\
17.6 \\
26.4\end{array}$ & $\begin{array}{r}355 \\
31.6 \\
34.1\end{array}$ & $\begin{array}{r}212 \\
12.5 \\
18.9\end{array}$ & $\begin{array}{r}260 \\
23.1 \\
25.0\end{array}$ & $\begin{array}{r}347 \\
30.8 \\
26.3\end{array}$ & $\begin{array}{r}235 \\
20.9 \\
17.8\end{array}$ & $\begin{array}{r}208 \\
12.3 \\
18.5\end{array}$ & $\begin{array}{r}125 \\
11.0 \\
12.0\end{array}$ & $\begin{array}{r}208 \\
12.3 \\
18.5\end{array}$ & $\begin{array}{r}134 \\
11.9 \\
12.9\end{array}$ & $\begin{array}{r}198 \\
11.7 \\
17.6 \\
\end{array}$ & $\begin{array}{r}168 \\
14.9 \\
16.1 \\
\end{array}$ & $\begin{array}{r}708 \\
41.9\end{array}$ & $\begin{array}{r}581 \\
51.6\end{array}$ & $\begin{array}{r}1,123 \\
66.4\end{array}$ & $\begin{array}{r}1,047 \\
93.1\end{array}$ \\
\hline
\end{tabular}


TABLE 3

READING TASKS

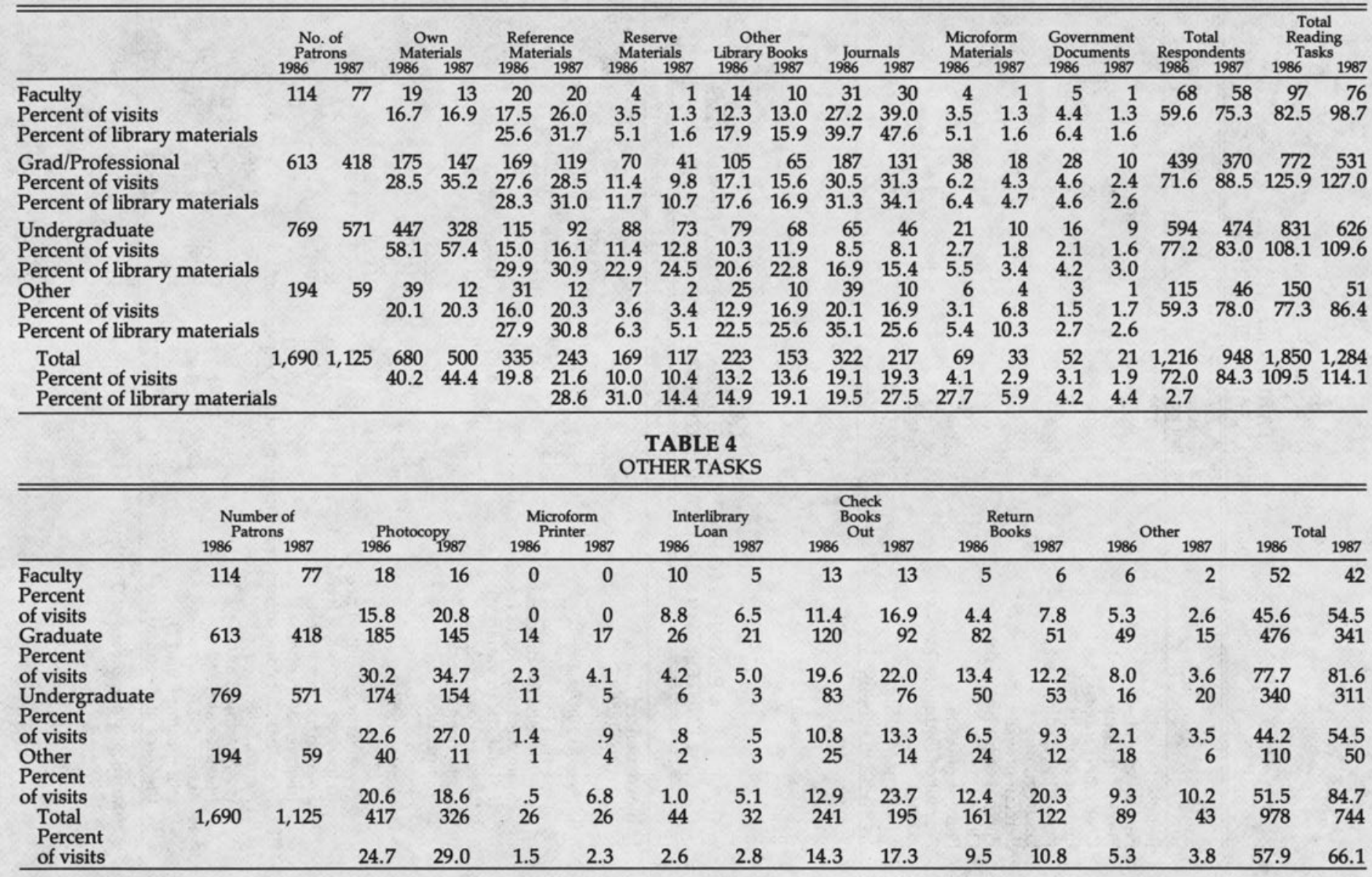


TABLE 5

1987 CARD CATALOG SEARCHES

\begin{tabular}{lccr}
\hline \hline & $\begin{array}{c}\text { Number of } \\
\text { Patrons }\end{array}$ & $\begin{array}{c}\text { Authorl } \\
\text { Title } \\
\text { Searches }\end{array}$ & $\begin{array}{c}\text { Subject } \\
\text { Searches }\end{array}$ \\
\hline Faculty & 77 & 8 & 3 \\
Percent of visits & & 10.4 & 3.9 \\
Percent of finding tasks & 418 & 8.2 & 3.1 \\
Graduate/Professional & & 35 & 27 \\
Percent of visits & & 8.4 & 6.5 \\
Percent of finding tasks & 571 & 5.5 & 4.2 \\
Undergraduate & & 21 & 17 \\
Percent of visits & 59 & 3.7 & 3.0 \\
Percent of finding tasks & & 4.1 & 3.4 \\
Other & & 4.4 & 11 \\
Percent of visits & 1,125 & 6.8 & 18.6 \\
Percent of finding tasks & & 5.2 & 14.3 \\
Total & & 68 & 58 \\
Percent of visits & & 5.2 & 5.2 \\
Percent of findings tasks & & & 4.4 \\
\hline
\end{tabular}

TABLE 6

MEAN TIME TO FIND AND CHECK OUT ITEMS, ONE AT A TIME MINUTES: SECONDS (STANDARD DEVIATIONS ARE IN PARENTHESES)

\begin{tabular}{|c|c|c|c|c|c|c|}
\hline & At Catalog & To Stacks & Return & Checkout & Total & $n$ \\
\hline \multicolumn{7}{|l|}{ I. Inexperienced Users } \\
\hline A. Acorn, 1986 & $1: 16$ & $2: 34$ & $2: 40$ & $: 45$ & $7: 15$ & 42 \\
\hline \multirow{2}{*}{ B. Acorn, 1987} & $\begin{array}{l}(133) \\
: 54\end{array}$ & $\begin{array}{l}(146) \\
3: 12\end{array}$ & $\begin{array}{l}(29) \\
1: 26\end{array}$ & $\begin{array}{l}(42) \\
: 38\end{array}$ & \multirow{5}{*}{$6: 10$} & 48 \\
\hline & (44) & (123) & ( 25$)$ & $(56)$ & & \\
\hline$T$ - Statistic for difference & 1.55 & $-1.65^{\prime}$ & $13.7^{\star \prime}$ & 0.7 & & \\
\hline $\begin{array}{l}F \text { - statistic in variances } \\
\text { (degrees of freedom) }\end{array}$ & $\begin{array}{r}4.47^{*} \\
(41.47)\end{array}$ & 0.74 & 1.34 & 0.56 & & \\
\hline \multicolumn{6}{|l|}{ II. Experienced Users } & \\
\hline C. Acorn, 1986 & $: 39$ & $2: 25$ & $2: 36$ & $: 35$ & $6: 15$ & 36 \\
\hline D. Acorn, 1987 & $: 48$ & $2: 50$ & $1: 13$ & 34 & \multirow[t]{3}{*}{$5: 25$} & 48 \\
\hline$T$ - statistic for difference & -1.64 & $\begin{array}{l}(190) \\
-.76\end{array}$ & $11.8^{\star}$ & $.17^{\star}$ & & \\
\hline $\begin{array}{l}\text { in means (degrees of freedom) } \\
F \text { - statistic in variances } \\
\text { (degrees of freedom) }\end{array}$ & $\begin{array}{c}(82) \\
0.78 \\
(35,47)\end{array}$ & 0.12 & $6.25^{*}$ & 0.74 & & \\
\hline \multicolumn{7}{|c|}{ III. $T$ - statistic for comparison of inexperienced and experienced users } \\
\hline \multirow{3}{*}{$\begin{array}{l}\text { E. Acorn, } 1986 \\
\text { (comparing } A \text { and } C \text { ) } \\
\text { (degrees of freedom) } \\
\text { F. Acorn, } 1987 \\
\text { (comparing } B \text { and } D \text { ) } \\
\text { (degrees of freedom) }\end{array}$} & $2.71^{*}$ & 0.75 & 0.40 & 1.29 & & \\
\hline & ( 76$)$ & $\begin{array}{l}(70) \\
0.70\end{array}$ & $\left(\begin{array}{l}70) \\
93 *\end{array}\right.$ & $(70)$ & & \\
\hline & $(77)$ & $(81)$ & ( 84$)$ & & & \\
\hline
\end{tabular}

*Statistically significant at 0.01 level. 
1986-1987

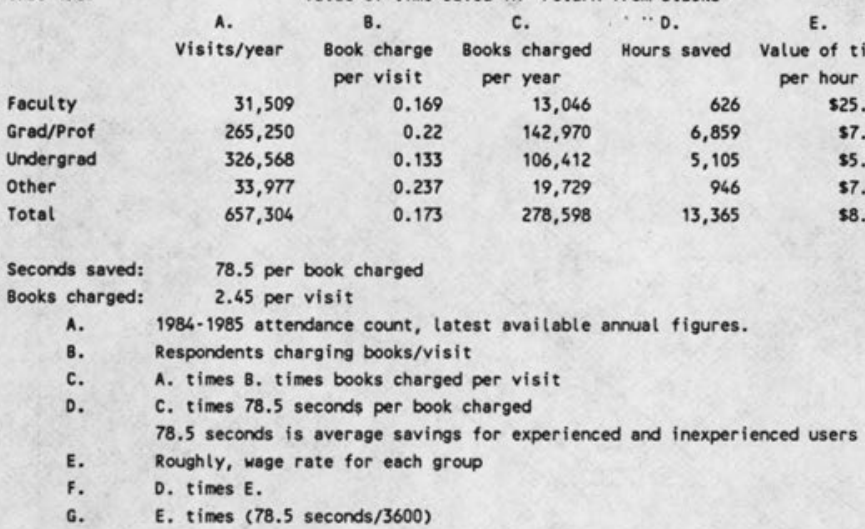

FIGURE 1

books charged to users per year.

To find the number of hours saved, multiply column $C$ by 78.5 seconds per book and convert to hours. Column $E$ repeats the hourly value of time used for each class in the 1987 essay on benefits. Column $F$ multiplies the number of hours in $D$ by the value per hour in $E$ to arrive at the total dollar value of the time saved by library users through the automated circulation system.

Figure 1 then reports a total benefit to users of the automated circulation system of $\$ 115,340$ per year. This excludes potential benefits in the law, medical, and music libraries because implementation varies in those libraries. Also excluded are the benefits of prompt overdue notification and the reporting of circulation status. This benefit is in addition to the benefits of the online catalog estimated in the 1987 essay. The benefit can be disaggregated by category of user as in column $F$ of table 7 .

The benefit can also be represented on a per transaction basis as in column $G$ of figure 1 , by using the system at the hourly rate of each class of user. For faculty, the time saved is worth about $\$ 1.20$; for undergraduates, $\$ 0.24$ per book charged.

\section{AVAILABILITY}

With the automated circulation component in use along with the automated acquisition tracking in the integrated system, the measure of availability can be traced more easily. The method involves asking persons using the catalog whether they are looking for a specific item. Each person who is, is asked to complete a form giving the author and title, call number if it is found, and to indicate whether the book is found. With the integrated system, a report of the status of the book can be shown on the system. Figure 2 shows our modification of Paul Kantor's form.

Figure 3 reports the measure of availability for spring 1985, fall 1985, and for spring 1987 . The conditional success rate is the proportion of users who successfully complete a particular step in searching, given that the preceding steps are successful. For example, 92.2 percent of the users found items in the catalog when they in fact were described in the catalog; 7.8 percent did not find the items in the catalog. Similarly, 77.3 percent found that items owned by the library had not been checked out; 22.7 percent looked for items that were in circulation. The product of the conditional success rates is the overall success rate. ${ }^{5}$

The probability of a user finding a specific item sought on the shelf at central library was 57.5 percent in period one, 64.1 percent in period two, and 45.0 percent in period three. The sources of variation in this aggregate measure are uncertain and will be explored in future investigation. Heretofore, the availability survey has been conducted at times convenient to the 


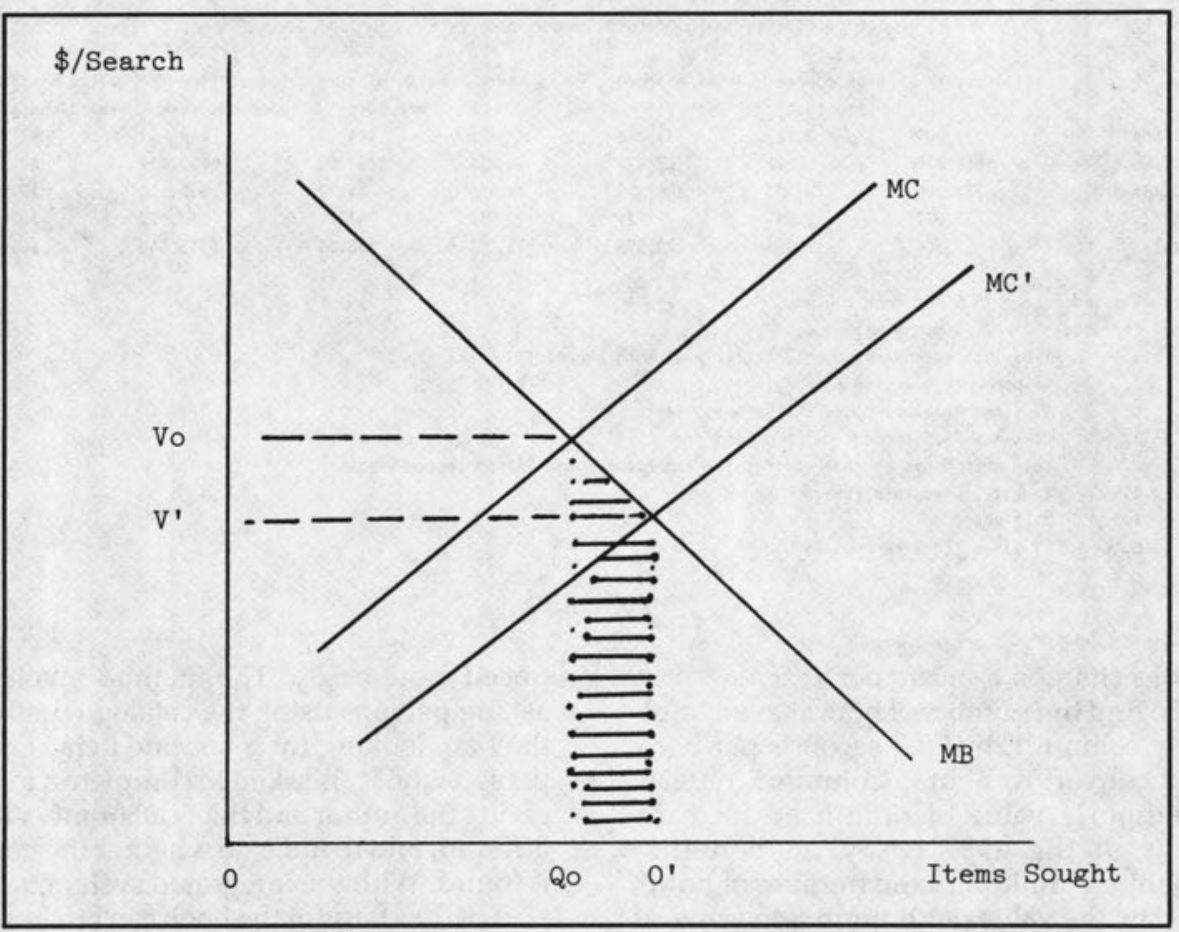

MB: Marginal benefit in dollar terms from one more unit of search, given that a particular amount of search has already been completed. MC: marginal cost, primarily in user time, of additional units of search. MC': the lower schedule of searching cost resulting from improvements due to automation. $\mathrm{V}_{\mathrm{o}}$ : The value of the last search before automation. $\mathrm{Q}_{\mathrm{o}}$ : the quantity of search performed before automation. $V^{\prime}$ : the value of the last unit of search given automation. $Q^{\prime}$ : the quantity of search performed given automation. The area of the trapezoid under $M B$ from $Q_{0}$ to $Q^{\prime}$ : the value of the increased search performed as a consequence of the fall in cost (user time) to complete a search given automation.

FIGURE 2

Marginal Benefits and Costs of Search

library staff members who must find out why users can not find the items they seek. In the future, randomly chosen twohour time blocks over a semester will be surveyed so that all the users are equally likely to be included. Also in the future, we will ask participants to indicate their status: faculty, graduate and professional school student, undergraduate. In this way, conditional success rates for knownitem searches by status of user will be available.

The success rate for known-item searches by library users reflects both the behavior of the library in selecting and managing its collection and the behavior of library users in seeking materials. The large increase in searching from 1985 to
1987 is associated with a decline in the rate of successes per search. The absolute number of successful searches increased markedly. The number of unsuccessful searches grew even more rapidly. To understand the sources of change in the success rate, a more sophisticated description of both the library operations and of the users' searching behavior must be developed. What determines the amount of searching by library users?

In the 1987 essay, the only benefit from improved known-item searching confidently ascribed to Acorn was due to the fact that it was a union catalog. In the 1987 result, again a significant number of searches would have been failures if limited to a card catalog of the central library's 


\begin{tabular}{|c|c|c|c|c|c|c|}
\hline & \multicolumn{3}{|c|}{$\begin{array}{c}\text { COUNT } \\
m=z=m=z=z=\end{array}$} & \multicolumn{3}{|c|}{ 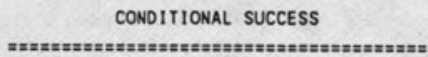 } \\
\hline & Spring 1985 & Fall 1985 & 1987 & Spring 1985 & Fall 1985 & 1987 \\
\hline & \multicolumn{6}{|c|}{ 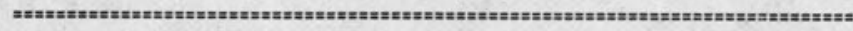 } \\
\hline 1. n (total-discards) & 637 & 325 & 420 & & & \\
\hline 2. Found on shelf at Central & 367 & 208 & 189 & $57.6 \%$ & $64.0 \%$ & $45.0 \%$ \\
\hline 3. Not found on shelf at Central & 253 & 114 & 209 & $42.4 \%$ & $35.1 \%$ & $55.0 \%$ \\
\hline Illegible titles & 17 & 3 & 22 & & & \\
\hline Never ordered & 721 & 221 & 451 & 1 & 1 & 1 \\
\hline Ordered, not available & $6>$ & $0>$ & $3>$ & $87.8 \%>82.4 \%$ & $93.5 \%>85.5 \%$ & $88.6 \%>72.8 \%$ \\
\hline At other divisions & 341 & 251 & 661 & 1 & 1 & 1 \\
\hline In catalog but missed & 17 & 14 & 24 & $96.7 \%$ & $95.2 \%$ & $92.2 \%$ \\
\hline Checked out & 51 & 30 & 64 & $89.9 \%$ & $88.6 \%$ & $77.3 \%$ \\
\hline On reserve or missing & 65 & 22 & 20 & $85.7 \%$ & $90.6 \%$ & $90.8 \%$ \\
\hline On shelf but missed & 25 & 4 & 9 & $93.6 \%$ & $98.1 \%$ & $95.4 \%$ \\
\hline Dverall success at Central & & & & $57.5 \%$ & $64.1 \%$ & $45.0 \%$ \\
\hline Dverall success at system & & & & $61.2 \%$ & $70.1 \%$ & $54.5 \%$ \\
\hline
\end{tabular}

\footnotetext{
* of 66 at other divisions, only 47 have potential to be hits, and if the percentage rate of hits at Central on available items is the same for the other divisions, then only 40 will be available.
}

\section{FIGURE 3}

Measures of Availability

collection, but that, in fact, are successes from the point of view of the university library system. The gain in success rate due to the union catalog effect is the difference between the 45.0 percent success at central alone, versus the 54.5 percent rate if success is defined in terms of the whole system. Despite the underlying unexplained variability in the conditional success rate, the benefit of the union catalog effect persists.

The value of the increased success rate for known-item searches is estimated in Figure 4, assuming a value of one dollar for each extra success due to the union catalog effect as developed in the 1987 essay. The level of author and title searching is substantially higher in 1987, and so the level of benefit from the union catalog effect is commensurately higher, namely, $\$ 28,505$ if finding a book is worth $\$ 1$. Given the variability of the known-item success rate, the average union catalog effect over the three years might be our best measure of this benefit, that is 6.4 percent points increase in success.

\section{VALUE OF MORE SEARCHING}

The increased number of searches performed as searching becomes more convenient with the electronic system might be valued in dollar terms. If the added searches were not performed under the older system, the users must have valued the searches at less than the time required to undertake them. The extra searches now undertaken are worth more than the value of the time required to complete them. Because people allocate their time among competing activities in ways that reveal an implicit dollar valuation on time, a reasonable valuation of time in estimating the value of the increased number of searches can be assumed.

As noted above, the level of author-title searching in Acorn increased in the second year of service. For the base period reported in the 1987 essay, a total of 115,686 


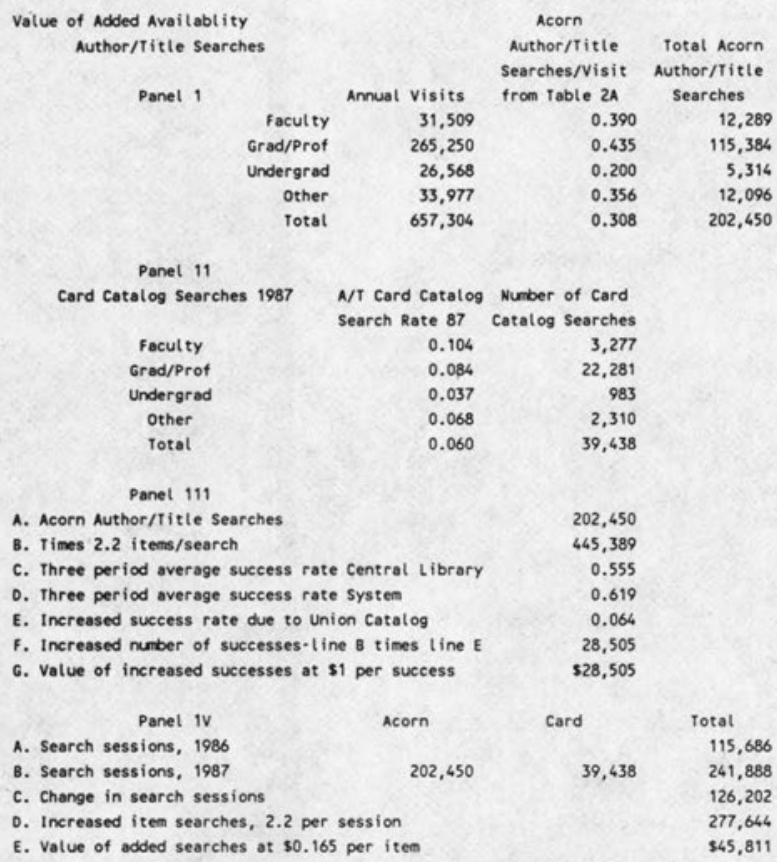

FIGURE 4

author-title search sessions were performed per year. In 1987, the total number of author-title search sessions in Acorn is estimated at 202,450. In addition, 39,438 search sessions used the card catalog. Assuming 2.2 searches per session, the total number of search sessions per year increased by 126,202 . With 2.2 items per session, that comes to 277,644 more items searched. The number of searches is computed in figure $4 .^{6}$

"In 1985, the time 'at catalog' was 84 seconds for inexperienced searchers. In 1987, the time 'at catalog' dropped to 54 seconds."

One more author-title search is worth at least the time it takes to complete it. In 1985 , the time "at catalog" was 84 seconds for inexperienced searchers. If users valued their time at $\$ 8.63$ per hour on average, then 84 seconds is worth $\$ 0.20$. In 1987 , the time "at catalog" dropped to 54 seconds, worth $\$ 0.13$, on average. In figure 2, $V o$ is $\$ 0.20$ and $V^{\prime}$ is $\$ 0.13$. The area of the shaded trapezoid represents the value of the added searches. ${ }^{7}$ If the marginal benefit curve is a straight line, the average value of the added searches will be approximately $\$ 0.165$ per search.

In the base period, the 115,686 authortitle search sessions searched for 254,509 items. In 1987, the 241,888 search sessions searched for 532,153 items. The increase of 277,644 items searched has a value of $\$ 45,811$ when valued at $\$ 0.165$. Notice that the searches are valued at $\$ 0.165$ per item whether successful or not. This benefit is in addition to the benefit of the improved success rate due to the union catalog effect.

The increased quantity of successful known-item searches undoubtedly leads to increased use of library materials and that would be a further benefit of the online system. At this point, there is no estimate of the increased use of materials.

\section{SUMMARY}

The benefits to users of the integrated 


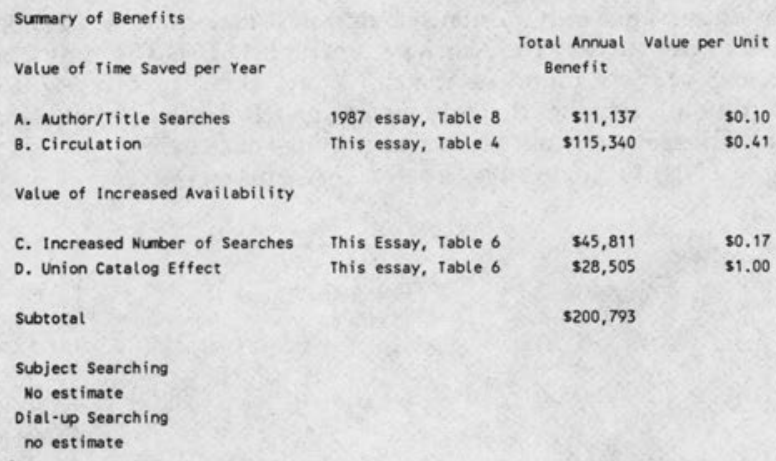

FIGURE 5

Summary of Benefits

online system measured so far at Vanderbilt come to $\$ 200,793$ per year as summarized in figure 5 . The largest benefit derives from the time saved with the circulation system, $\$ 115,340$ per year. Benefits of about $\$ 85,000$ per year derive from measured gains in known-item searching. There may be further benefits in known-item searching that remain hidden because of the inability to explain to a satisfactory degree the variation in the known-item success rate.

Of course, there are other categories of benefit that are as yet unmeasured. Subject searching constitutes about one third of all Acorn searching. If its value per search were similar to that for known item searches, another $\$ 40,000$ or so per year of benefit might be found. There will be significant benefits from all searching done outside the library by use of data com- munication links to Acorn because such network searching may reduce the number of visits to the library and so save users time.

There may be benefits from improved management of the library and its collections as we gain more complete information about patterns of use. The provision of online services delivered to individual desks across campus and beyond may induce an even more fundamental shift in the character of information services in a university setting, a link to nationally distributed databases and document delivery that may reduce emphasis on local collections.

At this point, the benefits of the online system are significant. As users gain experience with the online system, the level of benefit increases. Added functions add benefits as well.

\section{REFERENCES AND NOTES}

1. Malcolm Getz, "Some Benefits of the Online Catalog," College \& Research Libraries, 48, no.3:224-40.

2. Paul Kantor, Objective Performance Measures for Academic and Research Libraries. (Washington, D.C.: Assn. of Research Libraries, 1984).

3. We can compare, for inexperienced users, the mean time of 84 seconds at the card catalog in 1985 with the mean time of 54 seconds in 1987, the second year of the electronic world. The variances are not different and the $t$-statistic to test whether these means are different is 3.25 . The 30 -second time savings from 1985 to 1987 is a statistically significant difference from zero.

4. Most readers will be willing to spend money to avoid extra time in locating materials. The wage rate is an approximation of how much they would be willing to spend. We, then, value time at the hourly wage rate for undergraduates, graduate students, and faculty.

5. Paul Kantor, Objective Performance. 
6. The 202,450 reported sessions with 2.2 items sought per session implies 445,389 items searched per year as implied by our survey. The Acorn system reported 647,074 author and titles search in the year, but 212,693 of these found no match. Acorn, then, reports 647,074 minus 212,693, namely 434,381 author title searches that found some match. The survey information and the system information, then, seem to show similar magnitudes of searching.

7. Figure 1 is the same as figure 3 in the 1987 essay. 